\title{
Kedudukan Pancasila Sebagai Dasar Negara Pasca TAP MPR No.I/MPR/2003
}

\author{
Ashabul Kahpi \\ Universitas Islam Negeri (UIN) Makassar \\ Email: cavon.al@gmail.com
}

\begin{abstract}
This paper tries to see the position of Pancasila in the reality of nation and state. Pancasila is basically not just a blank slog that appears suddenly, but has the importance of trying to bring together universal values with local wisdom excavated by founding fathers as inclusive core values. That Pancasila is needed for a society that is highly fragmented by tribe, religion, language, and custom, besides the position of Pancasila as the legal norm and the ethics of state administration. No less important is that Pancasila also has significance as a national identity which then differentiates it from other nations. However, this seems to be considered reduced by some circles, especially after the issuance of MPR Decree No. I / MPR / 2003.
\end{abstract}

Keywords: Pancasila, Basic Country and Ideology of the Nation

\begin{abstract}
Abstrak
Tulisan ini mencoba melihat kedudukan Pancasila dalam realitas berbangsa dan bernegara. Pancasila pada dasarnya bukan hanya sekedar semboyan kosong yang muncul secara tiba-tiba, akan tetapi memiliki arti penting yang mencoba untuk mempertemukan nilai-nilai universal dengan kearifan lokal yang digali oleh para founding fathers sebagai core values inklusif. Bahwa Pancasila dibutuhkan untuk masyarakat yang sangat terfragmentasi oleh suku, agama, bahasa, maupun adat-istiadat, di samping kedudukan Pancasila sebagai norma hukum dan etika penyelenggaraan negara. Tidak kalah pentingnya adalah bahwa pancasila juga memiliki arti penting sebagai identitas nasional yang kemudian membedakan dari bangsa yang lainnya. Namun, hal ini tampaknya dianggap tereduksi oleh sebagian kalangan terlebih setelah dikeluarkannya TAP MPR No. I/MPR/2003.
\end{abstract}

Kata kunci : Pancasila, Dasar Negara dan Ideologi Bangsa 


\section{PENDAHULUAN}

7 ada tanggal 1 Juni 1945 , Soekarno ${ }^{1}$ dalam pidatonya menyatakan bahwa sebuah negara harus memiliki sebuah prinsip sebagai dasar negara, pada kesempatan tersebut pula, Soekarno mengusulkan lima prinsip dasar yang berisi kebangsaan Indonesia, internasionalisme atau perikemanusiaan, mufakat atau demokrasi, kesejahteraan sosial, dan yang terakhir ialah menyusun Indonesia Merdeka dengan bertaqwa kepada Tuhan Yang Maha Esa. Lima prinsip yang kemudian disebut oleh Soekarno dengan Pancasila yang berasal dari kata sila yang artinya asas atau dasar, selanjutnya di atas dasar itulah didirikannya Indonesia sebagai sebuah negara yang kekal dan abadi.

Kedudukan pancasila sebagai dasar Negara ini merupakan kedudukan yuridis formal oleh karena tertuang dalam ketentuan hukum Negara, dalam hal ini UUD 1945 pada bagian pembukaan alinea IV. Penegasan kedudukan Pancasila sebagai dasar Negara semakin kuat dengan keluarnya ketetapan MPR No.XVIII/MPR/1998 tentang penegasan Pancasila sebagai dasar Negara dan pencabutan ketetapan MPR No.II/MPR/1978 tentang P4, Pasal 1 ketetapan MPR tersebut menyatakan bahwa Pancasila sebagaimana dimaksud dalam pembukaan Undang-Undang Dasar 1945 adalah dasar Negara dari Negara kesatuan republik Indonesia yang harus dilaksanakan secara konsisten dalam kehidupan bernegara. Melalui TAP MPR No. I/MPR/2003, TAP MPR No. XVIII/MPR/1998 tersebut dikelompokkan ke dalam ketetapan MPR yang tidak perlu dilakukan tindakan hukum lebih lanjut, baik karena telah bersifat einmalig, telah dicabut, maupun telah dilaksanakan. Dengan demikian tidak ada satupun peraturan perundangundangan yang secara tegas mengatur kedudukan Pancasila sebagai dasar dan ideologi negara.

Perjalanan Pancasila sebagai dasar dan ideologi negara dapat dinyatakan sejalan dengan dinamika kebernegaraan dari segala aspeknya. Bersama itu pula aneka interpretasi dan multi tafsir yang berusaha me-reidealisasikan, mengintegrasikan atau sekedar mempersepsi sampai pada sikap menegasikan, menjadi gambaran nyata perjalanan Pancasila hingga saat ini. Periode awal memperlihatkan para tokoh kemerdekaan dari kalangan Islam "terpaksa"2

1 Pidato yang disampaikan tanpa persiapan tertulis terlebih dahulu yang akhirnya disepakati secara aklamasi oleh Dokuritzu Zyunbi Tyoosakai (BPUPKI). Lihat, Ronto, Pancasila sebagai Ideologi dan Dasar Negara, (Jakarta: PT. Balai Pustaka 2012)

${ }^{2}$ Atau meminjam istilah Soeharto (mantan Presiden RI) yang menyebutnya sebagai weweh tan kelangan- Ummat Islam memberi tanpa harus kehilangan, karena prinsip tauhid dalam ajaran Islam —Kemaha Esaan Tuhan — tidak hilang dari rumusan Ketuhanan Yang Maha Esa 
menerima rumusan dasar negara dan diantara mereka menganggap bahwa perdebatan mengenai lima sila Pancasila khususnya sila pertama masih dapat dilakukan setelah perang benar-benar telah selesai. Namun mereka menyadari bahwa pengorbanan semacam ini perlu dilakukan untuk mencapai kemerdekaan Indonesia dan menyatukan bangsa Indonesia

Lebih jauh lagi, realitas kenegaraan dan kebangsaan yang senantiasa mengarah pada keberadaban universal $^{3}$ searah dengan kemajuan zaman, memperlihatkan adanya serangkaian usaha yang berusaha merongrong keberadaan Pancasila yang berpuncak pada G30s 1965. Gerakan yang menandai munculnya sebuah periode baru kenegaraan dan kebangsaan. Orde yang berusaha mengembalikan Pancasila pada kedudukan yang semestinya, sekaligus menjaga Pancasila dari segala bentuk rongrongan yang diistilahkan dengan "AncamanTantangan-Hambatan-Gangguan (ATHG) ${ }^{4}$, baik yang berasal dari dalam maupun luar negeri. ${ }^{5}$ Meski dalam perjalanan selanjutnya orde ini-pun dianggap gagal mengemban amanah. Sebab yang terlihat (oleh sebagian kalangan) orde ini menjalankan usaha-usaha yang secara sitematik hendak menghilangkan dan menghapuskan "roh" bangsa - Pancasila- dari bumi indonesia. Bahwa pada masa ini Pancasila dinterpretasikan secara kaku dan pemaknaannya menjadi milik mutlak penguasa negara, yang pada kenyataannya justru dijadikan instrumen politik untuk menjaga status quo. ${ }^{6}$

Reformasi 1998 sebagai penanda berakhirnya ORBA mengawali "kePancasilaannya" dengan pencabutan TAP MPR RI No. II/MPR/1978 tentang P4 (ekaprasetia pancakarsa). Hal ini kemudian menyebabkan polemik dan adu

3 Seringkali disamakan dengan modernisasi, yaitu merujuk pada sebuah bentuk transformasi dari keadaan yang kurang maju atau kurang berkembang ke arah yang lebih baik dengan harapan akan tercapai kehidupan masyarakat yang lebih maju, berkembang, dan makmur.

${ }^{4}$ Meski pada dasarnya konsep ini merupakan konsep yang bersifat umum dari "early warning system" yang dipopulerkan oleh Suharto, berupa konsep kewaspadaan ketat terhadap Ancaman-Tantangan-Hambatan-Gangguan (ATHG)

${ }^{5}$ Potensi ATHG dalam negeri berupa bentuk-bentuk sikap atau perilaku yang berusaha mencederai komitmen teritori fisik dan cita-cita pembangunan peradaban sebagaimana diamanatkan Pancasila. Sedangkan ATHG dari luar negeri berupa upaya-upaya kalangan-kalangan asing yang berusaha melakukan pengendalian kebijakan maupun potensi strategis yang dampaknya dapat mempengaruhi kedaulatan bangsa. Lihat, Abd. Rahman, Konsepsi Peradaban Pancasila 4. http://soeharto.co/konsepsi-peradaban-pancasila-4

${ }^{6}$ Gumilar Rusliwa Somantri, Pancasila dalam Perubahan Sosial-Politik Indonesia Modern," dalam Restorasi Pancasila: Mendamaikan Politik Identitas dan Modernitas (Jakarta: Brighten Press, 2006), h. 8 
argumentasi dan persoalan yang nyaris tanpa akhir $^{7}$. Bagi sebagian kalangan, Penghapusan P4 pada era reformasi lebih dilatarbelakangi alasan emosionalpolitis, dengan menuding P4 digunakan sebagai sarana indoktrinasi Presiden Soeharto dalam melanggengkan kekuasaannya. Sementara golongan lainnya menyorot pertimbangan $\mathrm{MPR}^{8}$ yang dituangkan dalam huruf $\mathrm{b}$, yang menyatakan bahwa "P4 tidak sesuai dengan perkembangan kehidupan bernegara", sesuatu yang dinilai sangat sempit dalam memahami materi muatan yang ada dalam TAP MPR No. II Tahun 1978 tersebut. Karena jika dipahami secara mendalam, materi muatan yang ada dalam TAP MPR No. II Tahun 1978 tersebut bersifat universal dan merupakan pengontrol bangsa Indonesia dalam menjalani perkembangan kehidupan bernegara, sehingga tidak terjadi perkembangan kehidupan yang kebablasan dan tidak mengindahkan nilai-nilai atau acuan yang ada dalam Naskah P4 tersebut. ${ }^{9}$

Implikasi yang ditimbulkan sebagai yang dinyatakan oleh Abd. Rahman ${ }^{10}$ adalah terjadinya serangkaian kegagalan manejemen konflik nilai yang terlihat dari maraknya judicial review undang-undang akibat disharmonisasi antara philosophische grondslag dengan produk legislatif. Implikasi lain akibat rangkaian permasalahan ini adalah terkait dengan penegasan keberadaan Pancasila atas ditetapkannya Ketetapan MPR RI No. I/MPR/2003 yang menyatakan Ketetapan MPR RI No. XVIII/MPR/1998 tidak berlaku lagi.

Pada satu sisi keadaan-keadaan tersebut dalam kenyataanya memperlihatkan adanya kelompok-kelompok yang pesimis dan sinis terhadap usaha menjadikan Pancasila sebagai acuan dalam kehidupan bermasyarakat, berbangsa dan bernegara. Bahwa tetap membuka kemungkinan adanya maksud maksud lain dari kelompok-kelompok tersebut, yang menginginkan dasar negara

${ }^{7}$ Contoh nyata dalam masalah ini adalah penggunaan kalimat "4 pilar", lebih lanjut lihat, Prosiding Focus Group Discussion Pakar I: Kajian Ilmiah Masalah Perbedaan Pendapat 4 Pilar Kehidupan Berbangsa dan Bernegara (Kerjasama Pusat Studi Pancasila Universitas Gadjah Mada Dan Masyarakat Pengawal Pancasila Joglo-Semar, Bulaksumur UGM Yogyakarta, 14 September 2013)

${ }^{88}$ Majelis Permusyawaratan Rakyat RI, K E T E T A P A N Majelis Permusyawaratan Rakyat Republik Indonesia Nomor Xviii/Mpr/1998 Tentang Pencabutan Ketetapan Majelis Permusyawaratan Rakyat Republik Indonesia Nomor Ii/Mpr/1978 Tentang Pedoman Penghayatan Dan Pengamalan Pancasila (Ekaprasetia Pancakarsa) Dan Penetapan Tentang Penegasan Pancasila Sebagai Dasar Negara

9 Lihat. http://forumkajianhukumdankonstitusi.blogspot.co.id/2013/01/menatap-ulangperanan-serta-efektivitas_9989.html

${ }^{10}$ Abd. Rahman, P4 Sarana Edukasi Idiologi Bangsa [1]. http://soeharto.co/p4-saranaedukasi-idiologi-bangsa 
yang lain bagi bangsa Indonesia, baik yang bersifat sektarian maupun nonsektarian tertentu. Akan tetapi tetap, bahwa mereka pada dasarnya, mengingkari kenyataan yang dimiliki bangsa Indonesia sendiri yakni sebagai masyarakat majemuk, multikultural dan heterogenitas bangsa yang sangat pluralistik. Pada titik ini, mereka terlepas dari cara pandang rasional dan tanpa melihat Pancasila sebagai sebuah realitas objektif. ${ }^{11}$ Sementara di sisi lain, masih terdapat elemen-elemen bangsa dengan segenap daya dan upaya berusaha mengembalikan dan menyebar luaskan Pancasila ajaran Soekarno, agar semua warga negara Indonesia dapat memahami secara konprehensif, meyakini hakikat dan kebenarannya untuk kemudian berjuang atas pelaksanaannya. Termasuk usaha untuk "menegaskan Pancasila sebagai Dasar Negara, Ideologi Bangsa dan Negara".

\section{PEMBAHASAN}

Beberapa kalangan sepakat bahwa Pancasila sebagai ideologi nasional merupakan titik temu, rujukan bersama, commom platform, kesapakatan bersama dan nilai integratif bagi bangsa Indonesia, Pandangan bersama bahwa Pancasila adalah ideologi nasional inilah yang harus terus dipertahankan dan ditumbuh kembangkan dalam kehidupan bangsa yang majemuk ini. Oleh sebab hal tersebut, dengan meminjam materi bahasan pada kegiatan Focus Group Discussion MPR $R I^{12}$, pembahasan difokuskan pada permasalahan berikut $:^{13}$

\section{A. Pancasila Sebagai Norma Hukum dan Norma Etika Penyelenggara Negara}

Pada hakikatnya, Pancasila merupakan suatu sistem filsafat yang mengandung tataran nilai, yang dengan demikian merupakan sumber dari segala penjabaran norma baik norma hukum, norma moral maupun norma kenegaraan

11 Meminjam istilah prof. Dr. H. Kaelan,MS. yaitu "perspektif kausalitas" yang memandang Pancasila secara realitas objektif bangsa dan negara, meliputi; dasar legitimasi yuridis, filosofis, politis, historis dan kultural. Lihat, Prof.H. Kaelan, PROBLEM EPISTEMOLOGIS EMPAT PILAR BERBANGSA DAN BERNEGARA, dalam Prosiding Focus Group Discussion Pakar I: Kajian Ilmiah Masalah Perbedaan Pendapat 4 Pilar Kehidupan Berbangsa dan Bernegara (Kerjasama Pusat Studi Pancasila Universitas Gadjah Mada Dan Masyarakat Pengawal Pancasila Joglo-Semar, Bulaksumur UGM Yogyakarta, 14 September 2013), h. 38-39

${ }^{12}$ Majelis Permusyawaratan Rakyat RI, Term Of Reference Focus Group Discussion Penegasan Pancasila Sebagai Dasar Negara, Ideologi Bangsa dan Negara. Makassar 29 Maret 2017

${ }^{13}$ Majelis Permusyawaratan Rakyat RI, Term Of Reference Focus Group Discussion, h. 2-3 
lainnya. Dalam Filsafat Pancasila terkandung di dalamnya suatu pemikiranpemikiran yang bersifat kritis, mendasar, rasional, sistematis dan komperhensif (menyeluruh) dan sistem pemikiran ini merupakan suatu kumpulan nilai. Singkatnya, nilai yang dikandungnya dapat dikatakan sebagai hasil pertimbangan dan penilaian tentang "baik-buruknya" sesuatu yang kemudian dipergunakan sebagai motivasi untuk melakukan atau tidak melakukan sesuatu .

Dalam posisi ini, ketika nilai tersebut hendak diwujudkan dalam kehidupan nyata bermasyarakat, berbangsa dan bernegara, maka nilai-nilai tersebut dijabarkan kedalam bentuk norma yang jelas. Perwujudannya dapat berupa; pertama: norma hukum, yaitu sebagai suatu sistem peraturan dan perundang-undangan yang berlaku (diberlakukan) bagi segenap lapisan masyarakat, dan seharusnya tekanan pelaksanaannya lebih ditujukan bagi penyelenggara negara. Sebab penyelenggaraan negara tak dapat terjadi tanpa adanya landasan hukum, dus penyelenggara hendaknya demikian (wajib ditetapkan norma), agar penyelenggaraan negara dapat berjalan seiring dan seia dengan penyelenggaranya - penyelenggara negara adalah representasi Negaradan dengan demikian menegaskan Pancasila sebagai sumber dari segala sumber hukum tidak hanya sekedar semboyan kosong. Kedua: norma moral yang semakna dengan, kesusilaan, tabiat dan tingkah laku, maupun etika. Berdasar pada norma etika ini, hendak diukur baik dan buruk, kesopanan juga kesusilaan manusia Indonesia terkait tingkahlaku atau perbuatannya. Dengan demikian penyelenggara negara pada posisi ini berdiri pada dua titik, mereka adalah manusia Indonesia dan sekaligus (pemegang amanah) sebagai penyelenggara negara, atau dari sudut sosiologi penyelenggara terikat pada dua aspek yaitu etika individu dan etika sosial. Oleh sebab itu, dalam kapasitas nilai Pancasila yang telah terjabarkan ke dalam norma moralitas atau norma etika bermasyarakat, berbangsa dan bernegara, maka daya ikatnya terhadap penyelenggara negara (seharusnya) menjadi lebih kuat. Bahwa Republik Ini berdiri tegak dan dibangun di atas dasar dan Landasan Pancasila, maka konsekuensi realistisnya adalah :

1. siapapun yang mengaku sebagai orang Indonesia, maka wajib baginya untuk menjunjung tinggi nilai Pancasila,oleh sebab itu;

2. siapapun yang mengemban amanah sebagai penyelenggara Republik Indonesia wajib menjunjung tinggi nilai Pancasila;

3. sebagaimana, perlunya penyelenggaraan negara secara tegas (wajib) diatur berdasarkan Undang-undang maupun peraturan lainnya,demikian pula penyelenggara negara yang harus dikaitkan dan dilihat dalam satu kesatuan dengan penyelenggaraan Negara tersebut. 


\section{B. Pancasila Sebagai Dasar dan Haluan Penyusunan kebijakan Bidang Ekonomi, Politik dan SDM.}

Eka Dharmaputra ${ }^{14}$, menyatakan bahwa penginterpretasian pancasila bukan hanya sekedar interpretasi pada sebuah fase sejarah namun perlu juga adanya pemahaman terhadap masalah konkret kebangsaan yang bermunculan dari masa ke masa. Permasalahan konkret yang terlihat sama dihadapi oleh bangsabangsa di dunia berkisar pada masalah ekonomi, politik dan SDM. Secara simultan, bangsa Indonesia ter-ikut pada fenomena perubahan sosial, budaya, ekonomi maupun politik, yang menghendaki adanya perubahan perubahan mendasar terhadap pola pikir maupun pola hidup, baik pada tataran individu maupun pada tataran yang lebih luas yaitu berbangsa dan bernegara

Telah disinggung sebelumnya, bahwa Pancasila yang pada hakikatnya merupakan landasan filosofi (philosophische grondslag). Dalam pandangan ini, seluruh unsur kehidupan bangsa berakar pada nilai-nilai yang telah terpelihara, yang mengkristal menjadi hakikat dan realitas hidup bangsa secara keseluruhan dan dalam segala aspeknya. Tidak semata menjadi milik segolongan masyarakat, atau terhadap satu bidang tertentu saja.

Jika permasalahannya terkait pada penegasan keberadaan Pancasila sebagai dasar dan haluan dalam menyusun kebijakan dalam segala bidang, maka jawabannya tetap harus merujuk pada muatan yang dikandung oleh Pancasila itu sendiri. Telah dimaklumi adanya, bahwa Pancasila merupakan sebuah konsepsi peradaban yang diletakkan diatas nilai-nilai transendensi (kebertuhanan), perlindungan terhadap martabat kemanusiaan , Kesatuan dan kebersamaan dalam keberagaman, terselenggaranya sistem demokrasi yang dibimbing oleh hikmat kebijaksanaan dalam penyelenggaraan negara, dan kemauan kuat untuk mewujudkan keadilan sosial bagi seluruh rakyat.

Merujuk pada konsep-konsep yang terkandung dalam Pancasila yang multi dimensional, dan terkait pada aspek etika sosial, akan terlihat bahwa Etika sosial memuat banyak etika yang khusus mengenai wilayah-wilayah kehidupan manusia tertentu, termasuk etika politik yang menyangkut dimensi politis manusia. Dalam hal ini, meski pembahasan etika politik adalah hubungan-hubungan antar masyarakat dan negara, akan tetapi etika politik tetap meletakkan dasar fundamental manusia sebagai manusia. Dasar ini lebih meneguhkan akar etika politik bahwa kebaikan senantiasa didasarkan kepada hakikat keberadaban.

${ }^{14}$ Eka Darmaputera, Pancasila: identitas dan modernitas : tinjauan etis dan budaya, (Jakarta: BPK Gunung Mulia, 1987), h. 
Berdasarkan suatu kenyataan bahwa masyarakat, bangsa maupun negara bisa berkembang ke arah keadaan yang tidak baik dalam arti moral.

Contoh yang dapat direnungkan dalam hal ini misalnya, adanya kompetisi antara pendukung konsep privatisasi BUMN, percepatan investasi dengan penghalalan peran luas swasta asing serta pendukung kedaulatan ekonomi rakyat yang satu sama lain tidak terintegrasi kedalam proporsi keseimbangan peran dalam kerangka visi umum pembangunan ekonomi nasional. Tidak adanya road map terintegrasi dan visi umum yang membalut semua agenda pengembangan pilar-pilar perekonomian tersebut menjadikan swasta asing tumbuh sedemikian cepat meninggalkan swasta nasional dan kelompok usaha mikro-koperasi. ${ }^{15}$ Sejatinya, pembangunan ekonomi yang dapat bertahan dan mantap pada kenyataannya hanya dapat terjadi jika disertai oleh perubahan dalam sistem nilai dan struktur sosial, yang menghendaki adanya transformasi nilai. ${ }^{16}$

Jika suatu negara dalam penyelenggaraanya dikuasai oleh penguasa atau rezim yang otoriter, atau penguasaan sumber-sumber ekonomi oleh segolongan kelompok tertentu atau bentuk-bentuk pememaksaan kehendak lainnya kepada manusia atau kelompok lain tanpa memperhitungkan dan mendasarkan kepada hak-hak dasar kemanusiaan, maka pada aspek inilah akan terasa perlunya dasardasar dan haluan tersebut. Oleh karena itu (setidaknya) sebagai langkah antisipatif, Pancasila dengan nilai-nilai yang dikandungnya masih perlu dijadikan dasar dan haluan dalam penyusunan kebijakan. Hal ini paling tidak untuk menjawab tudingan bahwa pada era reformasi ini, wacana politik Indonesia lebih mengedepankan isu-isu pragmatis, misalnya bidang ekonomi (khususnya statistik dagang) yang sejak awal memang tidak memiliki kekuatan untuk diperhitungkan.

\section{Pancasila Sebagai Kajian Ilmu dalam Sistem Pendidikan Indonesia}

Guna keperluan penulisan ini, maka pada beberapa kesempatan diadakan diskusi singkat dan tanya jawab ${ }^{17}$ bersama mahasiswa. Adapun pertanyaan yang

${ }^{15}$ Abd. Rahman, P4 Sarana Edukasi Ideologi Bangsa. http://soeharto.co/p4-saranaedukasi-idiologi-bangsa

${ }^{16}$ Eka Darmaputra, Pergulatan kehadiran Kristen di Indonesia: teks-teks terpilih Eka Darmaputera, (Jakarta: BPK Gunung Mulia, 2001), h. 198

${ }^{17}$ Diadakan pada hari senin 27 Maret 2017, terhadap sekira 200-an mahasiswa Fakultas Syari'ah dan Hukum UIN Alauddin Makassar. Meski hasil yang didapatkan belum cukup valid untuk dijadikan dasar acuan, akan tetapi sebagai data awal hasil yang didapat setidaknya dapat memberikan gambaran, dan tidak bermaksud untuk mengeneralisasi mahasiswa (peserta didik) pada umumnya. 
dikemukakan adalah 6 poin yang dikemukakan dalam TOR FGD MPR RI. Hasil yang diperoleh diturunkan sebagai berikut :

1. Semua (100\%) mahasiswa mengetahui apa itu Pancasila (sebagai istilah)

2. Setidaknya $80 \%$ TIDAK mengetahui apa itu P4 (baik istilah maupun substansinya)

3. Bahwa setidaknya $99 \%$ mahasiswa menganggap bahwa Pancasila sebagai suatu kajian ilmu (mis, Pendidikan Pancasila dan Kewarganegaraan) masih dan tetap diperlukan (hanya masalah penyesuaian materi)

4. Semua mahasiswa sepakat terhadap poin 1 dan 2 TOR (perlu ditegaskan)

Berdasar pada hasil tersebut, dapat dikemukakan bahwa Pancasila sebagai yang dikenal dewasa ini hanyalah Pancasila dari segi istilahnya, maka adalah hal yang lumrah jika masih ada mahasiswa (bahkan bejabat negara) yang tidak/belum menghapal sila-sila Pancasila, atau paling tidak, mengurutkannya secara benar. Lebih jauh lagi, kenyataan P4 hanyalah sebuah singkatan, tanpa mengetahui bahwa P4 adalah akronim dari Pedoman Penghayatan dan Pengamalan Pancasila $^{18}$. Padahal P4 itu secara substansial merupakan transformasi philosophische grondslag - dalam penyelenggaraan edukasi publik. Dengan alasan ini pula, fungsi strategis P4 sebagai media atau forum edukasi politik kebangsaan yang terhapuskan keberadaanya , seharusnya (perlu) dicarikan format pengganti yang lebih baik. Akan tetapi hal yang patut disyukuri adalah masih adanya kesadaran pada perlunya Pancasila itu diajarkan (MP maupun MK) dengan penekanan pada substasi dan materi serta sistem pengajarannya yang disesuaikan dengan "zaman sekarang". Oleh sebab hal tersebut, dapat dinyatakan bahwa keberadaan Pancasila sebagai suatu Kajian ilmu tersendiri tetap diperlukan, dengan mengikut dan menyesuaikan dengan perkembangan zaman tanpa tercerabut dari dasarnya (Pancasila itu sendiri).

\section{Kebijakan Konkret}

Menurut Alfian terdapat empat faktor yang dapat menjadikan suatu ideologi tetap dapat bertahan dan menjadi ideologi yang tangguh, yakni (1) bahwa ideologi tersebut berisi nilai dasar yang berkualitas, (2) bahwa ideologi tersebut dipahami, lalu terkait sikap dan tingkah laku masyarakat terhadapnya, (3) terdapat

${ }^{18}$ Hal yang mungkin masih dapat dimengerti sebab terjadi setelah ditetapkannya TAP MPR No. XVIII tahun 1998 yang mencabut TAP MPR II tahun 1978 tentang P4. 
kemampuan masyarakat untuk mengembangkan pemikiran-pemikiran yang relevan dengan ideologi tersebut tanpa menghilangkan jatidiri ideologi dimaksud, dan (4) seberapa jauh nilai-nilai yang terkandung dalam ideologi itu membudaya dan diamalkan dalam kehidupan bermasyarakat, berbangsa dan bernegara.

Dalam tataran tersebut, implementasi Pancasila dalam pembuatan kebijakan publik haruslah lebih menitik beratkan pada operasionalisasi semangat dan keberpihakan kepada kepentingan rakyat banyak dalam penyusunan dan penetapan peraturan dan perundang-undangan. Meski hal tersebut tidak dapat secara praktis dilakukan, dan harus melalui upaya-upaya yang simultan, sistematis dan berkesinambungan. Namun yang terpenting dalam hal ini adalah adanya kemauan dan keinginan untuk terus berbuat, dengan pertimbangan bahwa Pancasila sebagai ideologis terbuka dalam dimensi fleksibilitasnya, berarti membuka peluang lahirnya ide-ide dan dan gagasan berkemajuan baik yang bersifat mengganti atau sekedar menyesuaikan dengan tuntutan zaman tanpa meninggalkan nilai intristik Pancasila. ${ }^{19}$

Selanjutnya, dengan asumsi bahwa yang salah bukanlah Pancasila tetapi kesalahan berada pada tataran pelaksanaannya. Maka yang diperlukan adalah membuka kembali lembar-lembar sejarah kebangsaan dan kebernegaraan dalam mewujudnyatakan nilai-nilai Pancasila, memilah dan memilih hal-hal yang masih berkesesuaian dengan masa sekarang (realitas sosial), untuk selanjutnya (jika dirasa perlu) ditetapkan dalam format baru. Termasuk kedalamnya adalah menemukan titik silang dan titik temu antar sila, sehingga koherensi antar sila dapat terjaga. Mungkin yang dapat dilakukan adalah koreksi terhadap penafsiran utopis atas sila-sila Pancasila, yang dalam kenyataanya lebih mengedepankan pendekatan filosofis-ideologis ${ }^{20}$, sehingga yang tampak hanyalah slogan-slogan kosong tanpa makna. Memadupadankan sila-sila Pancasila tidak dapat dilakukan melalui penafsiran sila-silanya secara parsial, sebab besar kemungkinan akan terjadi pertentangan antar sila itu sendiri, misalnya sila pertama yang bermaka religius-transendent akan terlihat bertentangan dengan ke-empat sila yang lain yang tampaknya "sekuler". Oleh sebab itu sila-sila Pancasila hendaklah ditafsirkan secara multidimensional dan dengan penafsiran sila yang satu dimulai dengan menggunakan sila lainnya. Dengan demikian output nilai yang dihasilkannya tidak saling bertentangan justru saling mendukung.

19 Asumsinya adalah bahwa merubah dan memodifikasi Mata Kuliah tidak harus dilakukan dengan merubah Fakultasnya, apalagi Universitasnya.

${ }^{20}$ Meskipun jantung dan jiwa utama Pancasila terdapat pada sila pertama, yang bersifat transenden. 


\section{E. Langkah Strategis Menjadikan Pancasila Sebagai Pancasila yang Melayani Segenap Lapisan Masyarakat}

Pancasila yang dikehendaki oleh segenap lapisan masyarakat tidak hanya Pancasila dalam tatanan idealnya, akan tetapi Pancasila Fungsional dan operasionalnya, hal ini bermakna Pancasila yang benar benar nyata dalam gerak dan langkah. Sebagai pembanding, dapat dikemukakan di sini tradisi dan kultur negara-bangsa. Amerika Serikat yang dikemukakan oleh Jean J. Kirkpatrick, dalam bukunya Rationalism and Reason in Politics, yang dikutip oleh M. Syafaat Habib, menggambarkan jatidiri bangsa Amerika sebagai berikut:

1. Selalu mengedepankan konsensus sebagai dasar legitimasi otoritas pemerintah.

2. Berbuat realistik sebagai tolok ukur realisme yang mendorong adanya harapan besar apa yang dapat diselesaikan oleh politik.

3. Mempergunakan belief reasoning dalam menata efektivitas rekayasa (engineering) kegiatan politik.

4. Langkah dan keputusan yang deterministik dalam mencapai tujuan multi demensi dengan selalu melalui konstitusi.

Pemahaman terhadap ungkapan "buang kulit dan ambil isinya" mungkin sudah tak relevan lagi, sebab sebagai sebuah bangsa besar Indonesia memiliki kekayaan dalam segala aspek yang dapat meneguhkan keberadaannya. Oleh sebab itu, baik itu euforia maupun fobia politik sudah seharusnya dibuang jauh-jauh sebab bukan merupakan jati diri bangsa yang sudah ada sejak lama, dengan demikian "buang kulit, pilah dan pilih isinya" mungkin lebih tepat jika ternyata kita masih memerlukan bahan dan material untuk membangun bangsa Indonesia.

Bahwa Negara adalah berasal dari rakyat, maka segala kebijaksanaan dan kekuasaan yang dilakukan senantiasa (berpihak) untuk rakyat. Oleh karena itu dalam pelaksanaan dan penyelenggaraan negara segala kebijaksanaan , kekuasaan serta kewenangan harus dikembalikan kepada rakyat sebagai pendukung pokok negara. Tersebab hal tersebut, maka dalam pelaksanaan politik praktis hal-hal yang menyangkut kekuasaan eksekutif, legislatif serta yudikatif, konsep pengambilan keputusan, pengawasan serta partisipasi harus berdasarkan legimitasi dari rakyat, atau dengan lain perkataan harus memiliki 'legimitasi demokratis' yang tersalur melalui kanal-kanal yang juga demokratis. 
Dengan meminjam pembahasan dan tulisan Abd Rahman ${ }^{21}$, maka langkah strategis yang dapat dilakukan adalah :

a. Konsolidasi Idiologi Bangsa yang berisikan; Konsistensi Pancasila Sebagai Idiologi Bangsa, Konsep Operasionalisasi Pancasila, Refungsionalisasi P4 sebagai Edukasi Publik Idiologi Bangsa

b. Transformasi Kesejarahan dan Manajemen Multikulturalisme Nusantara meliputi :

1) Transformasi Kesejarahan Peradaban Nusantara

2) Manajemen Multikulturalisme Nusantara

c. Stabilitas Keamanan Nasional, Untuk mewujudkan stabilitas keamanan nasional diperlukan pembenahan pada aspek-aspek berikut

1) Penyempurnaan Peraturan Hukum

2) Penyempurnaan Organisasi Dan Profesionalisme Aparat Hukum

3) Edukasi Publik Kepatuhan Hukum

4) Edukasi Publik HTAG (Early Warning System)

5) Way Out Kemacetan Hukum

d. Stabilitas Politik dan Pemerintahan, Mengacu pengalaman orde lama, orde baru dan realitas era reformasi, maka upaya mewujudkan stabilitas politik dan pemerintahan dapat dilakukan sebagai berikut:

1) Efektivitas Parliamentary Threshold

2) Refungsionalisasi GBHN

3) Percepatan Penanganan Korupsi Pejabat dan Elit Politik

4) Adanya Konsensus Manajemen Transisi

e. Redesain Road Map Pembangunan Kedaulatan dan Kemandirian Ekonomi Bangsa, Untuk melanjutkan upaya mewujudkan kedaulatan dan kemandirian ekonomi bangsa, perlu disusun road map dengan memperhatikan hal-hal berikut:

1) Pengelolaan Ekonomi Sesuai Amanat Pasal 33 UUD 1945

2) Penghentian Ekspor Energi

3) Road Map Pembangunan Industri

4) Pengelolaan dan Pengembangan Keunggulan Kompetitif

5) Sinergisitas Pusat-Daerah, Antar Kawasan Dan Kota-Desa

f. Implementasi Wawasan Nusantara

g. Konsistensi Visi Politik Luar Negeri

21 Abd. Rahman, Tujuh Langkah Rekonstruksi Peradaban Nusantara. http://soeharto.co/tujuh-langkah-rekonstruksi-peradaban-nusantara 


\section{F. Pancasila Sebagai Kritik Terhadap Kebijakan Negara.}

Dalam pelaksanaan dan penyelenggaraan negara, etika politik menuntut agar kekuasaan dalam negara dijalankan sesuai dengan (1) asas legalitas (legitimasi hukum), yaitu dijalankan sesuai dengan hukum yang berlaku, (2) disahkan dan dijalankan secara demokratis (legatimasi demokratis), dan (3) dilaksanakan berdasarkan prinsip-prinsip moral atau tidak bertentangan dengannya (legitimasi moral) ${ }^{22}$

Analisis berbagai pihak berkesimpulan, apabila penyelenggaraan pemerintahan tidak melaksanakan Pancasila secara konsisten - sesuai materi dan substansinya - maka akan mengalami kegagalan. Hal ini terbukti dari pengalaman sejarah baik selama Orde Lama maupun Orde Baru. Demikian halnya Orde Reformasi, apabila tidak melaksanakan Pancasila secara konsisten dalam menyelenggarakan kekuasannya akan mengulang kebali memori kelam kekeliruan orde sebelumnya, yang akan berakhir tidak saja dengan kejatuhan orde itu sendiri, bahkan terhadap sendi-sendi kebernegaraan. Oleh karena itu orang mulai bertanya-tanya bagaimana Pancasila dapat dengan tepat dan benar melandasi penyelenggara dan penyelenggeraan negara, dan bagaimana penerapannya bagi kehidupan bermasyarakat, berbangsa dan bernegara.

Bahwa perlu tidaknya Pancasila dijadikan sebagai kritik terhadap kebijakan negara telah terjawab pada uraian terdahulu. Jika segenap komponen bangsa telah sama menyadari dan melaksanakan Pancasila secara nyata murni dan konsekuen, maka kritik terhadap kebijakan negara tidak perlu lagi. Namun jika dirasa perlu menjaga pelaksanaan kebernegaraan tetap berada dalam koridor idealisasinya, maka Pancasila wajib dijadikan sebagai (alat) kritik kebijakan negara

\section{PENUTUP}

Sebagai penutup tulisan ini, maka baiknya direnungkan bersama pernyataan Nurchalis Madjid sebagai berikut :

Tidak ada bangsa yang dapat mencapai kebesaran, kecuali bangsa itu percaya kepada sesuatu, dan sesuatu yang dipercayainya itu memiliki dimensi-dimensi moral guna menopang peradaban yang besar. ${ }^{23}$.

\footnotetext{
${ }^{22}$ Frans Magnis Suseno, Etika Politik. Prinsip-Prinsip Moral Dasar Kenegaraan Modern (Jakarta:Gramedia,1987), h. 115

23 Nurcholish Madjid, Islam Doktrin dan Peradaban, (Jakarta: Yayasan Wakaf Paramadina, 1992), hlm xxiii
}

Jurisprudentie | Volume 4 Nomor 2 Desember 2017 
Adapun hasil telaah singkat dan pemahaman atas permasalahan sebagai terurai sebelumnya dapat disimpulkan sebagai berikut :

a. Bahwa Pancasila yang merupakan hasil kesepakatan bersama para Pendiri Bangsa merupakan "Perjanjian Luhur" sekaligus merupakan philosophische grondslag yang dengan demikian harus dijaga untuk selanjutnya diwariskan kepada genarasi penerus bangsa, yang salah satunya dapat dilakukan dengan cara,

b. Menjadikan Pancasila sebagai materi kajian (baik MP dan MK), yang dimaksudkan agar Pancasila tetap dinamis mengikuti perkembangan zaman. (poin 3). Disamping itu,

c. Pancasila harus ditetapkan sebagai norma hukum dan norma etika yang mewajibkan para penyelenggara menjunjung tinggi nilai-nilainya sebagai pedoman kebijakan dan tindakan (poin 1), sehingga

d. Penyusunan kebijakan dalam bidang ekonomi, politik dan pembangunan SDM dapat direalisasikan sesuai dengan Pancasila sebagai landasan utamanya (poin 2), yang dilakukan melalui;

e. Kebijakan konkret yang antara lain dengan menitik beratkan pada operasionalisasi semangat dan keberpihakan kepada kepentingan rakyat banyak dalam penyusunan dan penetapan peraturan dan perundangundangan. Disamping membuka peluang lahirnya ide-ide dan dan gagasan berkemajuan baik yang bersifat mengganti atau sekedar menyesuaikan dengan tuntutan zaman tanpa meninggalkan nilai intristik Pancasila (poin 4),

f. Guna menjadikan Pancasila menjadi Pancasila yang melayani segenap lapisan masyarakat maka diperlukan adanya langkah starategis yang meliputi Konsolidasi Idiologi Bangsa, Transformasi Kesejarahan dan Manajemen Multikulturalisme Nusantara, Stabilitas Keamanan Nasional, Stabilitas Politik dan Pemerintahan, Redesain Road Map Pembangunan Kedaulatan dan Kemandirian Ekonomi Bangsa, Implementasi Wawasan Nusantara serta Konsistensi Visi Politik Luar Negeri (poin 5), hal-hal tersebut dijadikan dasar untuk menjawab poin selanjutnya, bahwa

g. Perlu atau tidaknya Pancasila dijadikan kritik terhadap kebijakan negara akhirnya terpulang pada sejauh mana kita mampu melaksanakan 5 poin sebelumnya. 


\section{DAFTAR PUSTAKA}

Darmaputra, eka, pergulatan kehadiran kristen di indonesia: teks-teks terpilih eka darmaputera, jakarta: bpk gunung mulia, 2001

Kaelan, problem epistemologis empat pilar berbangsa dan bernegara, dalam mpr ri, prosiding focus group discussion pakar $i$ : kajian ilmiah masalah perbedaan pendapat 4 pilar kehidupan berbangsa dan bernegara (kerjasama pusat studi pancasila universitas gadjah mada dan masyarakat pengawal pancasila joglo-semar, bulaksumur ugm yogyakarta, 14 september 2013), h. 38-39

Madjid, nurcholish, islam doktrin dan peradaban, jakarta: yayasan wakaf paramadina, 1992

Majelis permusyawaratan rakyat ri, $k$ e t e t a $p$ a $n$ majelis permusyawaratan rakyat republik indonesia nomor xviii/mpr/1998 tentang pencabutan ketetapan majelis permusyawaratan rakyat republik indonesia nomor ii/mpr/1978 tentang pedoman penghayatan dan pengamalan pancasila (ekaprasetia pancakarsa) dan penetapan tentang penegasan pancasila sebagai dasar negara

Prosiding focus group discussion pakar i: kajian ilmiah masalah perbedaan pendapat 4 pilar kehidupan berbangsa dan bernegara (kerjasama pusat studi pancasila universitas gadjah mada dan masyarakat pengawal pancasila joglo-semar, bulaksumur ugm yogyakarta, 14 september 2013)

Ronto, pancasila sebagai ideologi dan dasar negara, jakarta: pt. Balai pustaka 2012

Somantri, gumilar rusliwa, pancasila dalam perubahan sosial-politik indonesia modern," dalam restorasi pancasila: mendamaikan politik identitas dan modernitas, jakarta: brighten press,2006

Suseno, frans magnis, etika politik. Prinsip-prinsip moral dasar kenegaraan modern, jakarta:gramedia, 1987

Suwarno, p.j., pancasila budaya bangsa indonesia, yogyakarta: kanisius, 1993 